\title{
Influence of reproductive qualities on dairy productivity of cows of the Simmental breed
}

\author{
Maria Grinchuk* and Yulia Nesterova \\ Kaliningrad State Technical University, Sovetsky prospect, 1, 236022, Kaliningrad, Russia
}

\begin{abstract}
The aim of work is to explore influence of first fruitful insemination, service period and dry period to dairy productivity of Simmental cows. The research is aimed at studying the milk production of Simmental cows with different levels of reproductive qualities. The result of the research, a relation was established between the age of the first fruitful insemination, the duration of the service period, the duration of the dry period and milk production performance. It has been established that the age of the first fruitful insemination at 18-24 months has the most beneficial effect on subsequent milk production. The service period of 90 120 days has a positive effect to an increase in milk yield per 305 days of lactation, the longer service period negatively affects to the mass fraction of fat. With an increase in the duration of the dry period, the mass fraction of fat increases, but milk yield decreases. The influence of reproductive qualities to the milk protein is negligible. It was revealed that the age of the first insemination at 18-24 months is the most profitable for production. According to the results of the research, it can be judged that reproductive qualities, in combination with other factors, affect the milk productivity of Simmental cows.
\end{abstract}

\section{Introduction}

Most of the factors affecting milk production have effect in combination, so it is not easy to establish the level of impact of each of them individually [1].

In dairy farming, simultaneously with an increase in productivity, a tendency for a decrease in reproductive capacity and a reduction in the length of the economical use of cows is found, which leads to a slowdown in the intensity of reproduction and the effectiveness of selection and breeding work [2]. A decrease in the age of pubescence and physiological maturity of heifers, that is, early maturity, is the main factor that determines the duration of use. Heredity, along with paratypical factors, affects the reproductive system and its successful functioning, including the age of reproductive use of livestock [3-4]. The main task of dairy farming is to intensify the industry by accelerating the increase in the genetic potential of animals [5-7].

Under conditions of intensification, the age of the first calving of Holsteinized animals should be 24-25 months, although the optimal age is 27-29 months [8]. Reducing the age of first calving allows you to reduce the cost of raising cows and get a larger number of

* Corresponding author: mariya.grinchuk@klgtu.ru 
offspring in the same period with early calving, which subsequently gives an increased production of milk and meat [9]. The combination of high milk productivity and good reproductive ability in animals is an important selection criterion in breeding work with dairy cattle [10].

This research analyzes the influence of the age of first insemination, the duration of the service period and the dry period on milk yield for 305 days of lactation, the milk fat, the milk protein on Simmental cows in the conditions of the peasant farm Tasaliev DM Kaliningrad region.

The aim of the research is to explore the milk productivity of Simmental cows with different levels of reproductive qualities.

\section{Materials and methods}

The assessment of reproductive qualities was carried out at the livestock enterprise of the peasant farm Tasaliev DM (Kaliningrad region) on Simmental cows $(n=56)$. During the research, the animals were under the same feeding and housing conditions.

During the experiment, the assessment of milk productivity (milk yield per 305 days of lactation, mass fraction of fat, mass fraction of protein) in cows with different levels of reproductive qualities (age of the first fruitful insemination, duration of the service period, duration of the dry period) was carried out.

The animals were divided into three groups. The first group included animals with an indicator below the average (recommended by literary sources), the third group - animals with an indicator above the average. Accordingly, the second group included animals with average reproduction rates. The research materials were the results of milk production and reproductive qualities of first-calf heifers and cows and reports on the production activities of the farm.

\section{Results}

Analysis of the data showed that first-calf heifers with the age of the first fruitful insemination of 18-24 months subsequently have a higher level of milk productivity (Table 1).

Table 1. Indicators of milk productivity in first-calf heifers depending on age at the first fruitful insemination

\begin{tabular}{|l|c|c|c|}
\hline \multirow{2}{*}{ Characteristic value } & \multicolumn{3}{|l|}{ Age of the first fruitful insemination, months } \\
\cline { 2 - 4 } & \multicolumn{1}{|l|}{$\mathbf{1 8}$} & $\mathbf{1 8 4}$ & \multicolumn{2}{l|}{} \\
\cline { 2 - 4 } & $\mathbf{( n = 1 3 )}$ & $\mathbf{( n = 3 2 )}$ & $\mathbf{( n = 1 1 )}$ \\
\hline $\begin{array}{l}\text { Milk yield per 305 days of } \\
\text { lactation, kg }\end{array}$ & 4285 & 4889 & 5001 \\
\hline MFF, \% & 4.10 & 4.23 & 4.29 \\
\hline MFP, \% & 3.3 & 3.3 & 3.3 \\
\hline Milk fat, kg & 173 & 207 & 186 \\
\hline Milk protein, kg & 141 & 162 & 330 \\
\hline $\begin{array}{l}\text { Milk fat and milk protein, } \\
\text { kg }\end{array}$ & 314 & 369 & \multirow{2}{*}{330} \\
\hline
\end{tabular}

Animals inseminated at the age of less than 18 months and more than 24 months were significantly inferior in milk yield to first-calf heifers aged 18-24 months $(\mathrm{P}<0.05)$.

There were no significant differences in the percentage of protein between the three groups ( $\mathrm{P}>0.05)$. 
With an increase in the age of first insemination, milk fat content in first-calf heifers significantly increased $(\mathrm{P}<0.05)$.

Corresponding results were obtained when analyzing the age of first calving. In firstcalf heifers with a calving age of 27-33 months, milk yield was significantly higher than in heifers calving at an age of less than 27 months $(\mathrm{P}<0.05)$.

In first-calf heifers with an early calving age, the MFF is $4.10 \%$, which is lower than the values of this indicator in the second and third groups by $0.13 \%$ and $0.19 \%$, respectively. According to calculations, the difference in values in the groups can be considered statistically significant $(\mathrm{P}<0.05)$. The percentage of protein in milk of later calving cows did not differ significantly. The results obtained indicate that insemination of heifers at the age of 18-24 months is most favorable for their subsequent milk production.

Despite the fact that first-calf heifers, inseminated at the age of over 24 months, had higher milk yield than those inseminated at 18-24 months, it is more rational to inseminate animals no later than 24 months, since for the additional time spent on raising heifers, milk yield increases insignificantly.

The next factor affecting the level of milk production is the regulation of the duration of lactation of the cow by choosing the period of insemination after calving [11-12]. The optimal duration of the service period is 45-60 days [13]. However, it is not always possible to regulate these periods, since not every insemination of a cow is fruitful, which is why there are differences in the duration of the service period. In this regard, during artificial insemination of cows, they try not to miss the emerging estrus.

Table 2 shows the indicators of milk production depending on the duration of the service period. There was a tendency to increase milk yield for 305 days of lactation in the group with a service period of 90-120 days, however, this tendency turned out to be statistically insignificant $(\mathrm{P}>0.05)$ (Table 2).

Table 2. Indicators of milk production in cows with different duration of the service period

\begin{tabular}{|l|c|c|c|}
\hline $\begin{array}{l}\text { Service period } \\
\text { duration }\end{array}$ & less than 90 days & $\mathbf{9 0}-\mathbf{1 2 0}$ days & over 120 days \\
\hline Characteristic value & $\mathbf{( n = 1 0 )}$ & $\mathbf{( n = 2 3 )}$ & $\mathbf{( n = 2 3 )}$ \\
\hline $\begin{array}{l}\text { Milk yield per 305 } \\
\text { days of lactation, kg }\end{array}$ & 5268.50 & 5764.52 & 5732.70 \\
\hline MFF, \% & 4.21 & 4.25 & 4.17 \\
\hline MFP, \% & 3.32 & 3.31 & 3.32 \\
\hline
\end{tabular}

An increase in the duration of the service period significantly leads to a decrease in the percentage of fat in milk $(\mathrm{P}<0.05)$. No statistically significant differences in protein percentage were found $(\mathrm{P}>0.05)$.

The results obtained indicate that the physiologically determined duration of the service period most favorably affects the increase in milk productivity (Figure 1). 


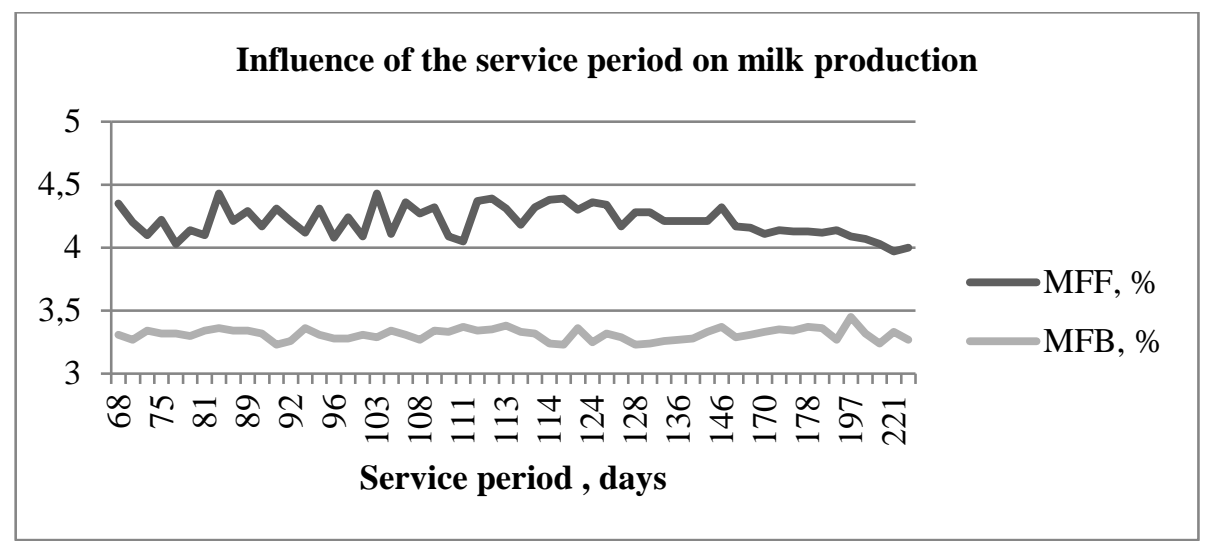

Fig. 1. Influence of the duration of the service period on the mass fraction of fat and mass fraction of protein

The service period has an even more significant effect on the reproductive capacity of cows than on milk production. Calf reproduction consists of two periods: the gestation period and the service period. Since the gestation period is relatively constant, equal to 285 days, the number of calves obtained from cows per unit of time of use depends mainly on the service period. With its increase, annual calf crop decreases [14].

Table 3. Calf crop depending on the duration of the service period

\begin{tabular}{|l|c|c|c|}
\hline $\begin{array}{l}\text { Service period } \\
\text { duration }\end{array}$ & less than 90 days & $\mathbf{9 0}-\mathbf{1 2 0}$ days & over 120 days \\
\hline Characteristic value & $\mathbf{( n = 1 0 )}$ & $\mathbf{( n = 2 3 )}$ & (n= 23) \\
\hline Calves, heads & 10 & 22 & 13 \\
\hline $\begin{array}{l}\text { Calves received per } \\
\mathbf{1 0 0} \text { heads, \% }\end{array}$ & 100 & 95.7 & 56.5 \\
\hline $\begin{array}{l}\text { Calf losses with an } \\
\text { extended service } \\
\text { period, \% }\end{array}$ & - & 4.3 & 43.5 \\
\hline
\end{tabular}

Table 3 shows that an increase in the duration of the service period leads to a significant loss of calves per year.

Table 4 shows the indicators of milk productivity depending on the length of the dry period. The highest milk yield in 305 days of lactation was found in cows with a dry period of 45-60 days, the lowest in cows with a dry period of more than 60 days, but, according to calculations, the dependence of milk yield on the duration of the dry period is statistically insignificant $(\mathrm{P}>0.05)$.

Table 4. Indicators of milk production in cows with different duration of the dry period

\begin{tabular}{|l|c|c|c|}
\hline $\begin{array}{l}\text { Duration of the dry } \\
\text { period }\end{array}$ & less than $\mathbf{4 5}$ days & $\mathbf{4 5 - 6 0}$ days & over 60 days \\
\hline $\begin{array}{l}\text { Characteristic } \\
\text { value }\end{array}$ & $\mathbf{( n = 1 1 )}$ & $\mathbf{( n = 2 6 )}$ & $\mathbf{( n = 1 9 )}$ \\
\hline $\begin{array}{l}\text { Milk yield per } \mathbf{3 0 5} \\
\text { days of lactation, } \\
\text { kg }\end{array}$ & 5749.18 & 5902.42 & 5733.84 \\
\hline MFF, \% & 4.20 & 4.24 & 4.26 \\
\hline MFP, \% & 3.32 & 3.32 & 3.32 \\
\hline
\end{tabular}


With an increase in the duration of the dry period, the mass fraction of fat in the milk of the studied livestock significantly increases, the highest percentage of fat was noted in the group with a duration of more than 60 days $(\mathrm{P}<0.05)$.

No statistically significant connection was found between the duration of the dry period and the mass fraction of protein in milk $(\mathrm{P}>0.05)$.

\section{Conclusion}

According to the results of the research, it can be estimated that reproductive qualities, along with other factors, affect the milk productivity of Simmental cows.

The age of the first fruitful insemination at 18-24 months has the most favorable effect on milk yield in 305 days of lactation, on the mass fraction of fat and the mass fraction of protein.

The physiologically determined duration of the service period of 90-120 days has a positive effect on increasing milk production. The average service period of the studied livestock was 125 days, which exceeds the norm by 5 days and reduces the calf crop. A shortened service period, that is, less than 90 days, due to the influence of the hormonal system, leads to a decrease in productivity after 305 days of lactation.

The advantageous effect of the dry period on increasing milk yield and fat mass fraction is observed with duration of 45-60 days. With an extended dry period, milk yield decreases, and the mass fraction of fat increases, with a shortened period, all indicators of milk productivity are inferior to other groups.

Based on the above, it is necessary to recommend the peasant farm "Tasaliev D.M." insemination of heifers no later than 21 months, when they reach a live weight of at least $380 \mathrm{~kg}$, which will contribute to the safety of newborn calves, increase milk productivity and reduce the cost of raising animals.

\section{References}

1. G.M. Tunikov, I.Yu. Bystrov, Biological bases of productivity of cattle. (PRIZ, Ryazan, 2014)

2. E.K. Stetskevich, The timing of the onset of physiological maturity and the reproductive capacity of heifers obtained by different biotechnological methods. 109110 (2015)

3. A.A. Shesternenkova, I.V. Manicheva, The influence of the genotype of cows on the indicators of reproductive function. Scientific journal of young scientists. 1, 24-26 (2019)

4. V.A. Bekenev, Productive longevity of a nimals, $m$ ethods of $i$ ts pr ediction an $d$ extension. Agricultural Biology. 54(4), 655-666 (2019)

5. M.B. Ulimbashev, Zh.T. Alagirova, Adaptive ability of Holstein cattle introduced into new habital conditions. Agricultural Biology. 51(2), 247-254 (2016)

6. O.M. Kishkevich, Yu.V. Istranin, Influence of the age of first calving and linearity on the $m$ ilk $p$ roductivity offir st-calf $c$ ows. Young researchers of agroindustrial and forestry complexes - to the regions. 3, 185-191 (2019)

7. Yu.V. Istranin, J.A. Istranina, Influence of Holsteinization on the milk productivity of cows. (Belgorod, 2018)

8. E.A. Levkin et al., Analytical a ssessment of modern us e of $i$ ndustrial and hi ghly specialized technologies for fattening cattle. Vet. journ. of Belarus. 2, 42-46 (2018)

9. A.V. Glaz et al., Ways to i ntensify he rd r eproduction i n c attle br eeding. (GGAU, Grodno, 2011) 
10. M.B. Ulimbashev, A.S. Tkhashigugova, E.R. Gosteva, Reproductive abi lity and immunological status of Simmental and crossbred cattle. Izvestiya TSKHA. 2, 82-91 (2015)

11. F.M. Gafarova, F.A. Gafarov Milk p roductivity a nd milk quality in fir st-calf h eifers depending on the duration of the service period. Materials of the All-Russian scientificpractical conference in the framework of the XXI International specialized exhibition "AgroComplex-2011". 138-140 (2011)

12. P.V. Vorobiev, A.F. Gabdrakhimova, E.O. Nikulina, Milk productivity and quality of milk of first-calf cows with different duration of the service period. Materials of the All-Russian scientific and practical conference. 41-44 (2017)

13. S.M. Anokhin et al., Milk productivity of first-calf heifers of Holstein and Si mmental breeds with different levels of reproductive qualities. Vestnik IRGSKhA. 93, 121-130 (2019)

14. R.N. Lyashuk, O.A. Mikhailova, Influence of the duration of the service period on milk productivity and reproductive ability of cows. Vestnik of OrelGAU. 6, 93-101 (2016) 